\title{
Contribution of Emotional Intelligence and Job Stress toward Job Satisfaction among Lecturers of Polytechnic
}

Nurfatin Diyana Hisya Muddin, Hazalizah Hamzah

To Link this Article: http://dx.doi.org/10.6007/IJARBSS/v11-i10/11498

DOI:10.6007/IJARBSS/v11-i10/11498

Received: 01 August 2021, Revised: 24 August 2021, Accepted: 20 September 2021

Published Online: 11 October 2021

In-Text Citation: (Muddin \& Hamzah, 2021)

To Cite this Article: Muddin, N. D. H., \& Hamzah, H. (2021). Contribution of Emotional Intelligence and Job Stress toward Job Satisfaction among Lecturers of Polytechnic. International Journal of Academic Research in Business and Social Sciences, 11(10), 1218 - 1226.

\section{Copyright: @ 2021 The Author(s)}

Published by Human Resource Management Academic Research Society (www.hrmars.com)

This article is published under the Creative Commons Attribution (CC BY 4.0) license. Anyone may reproduce, distribute, translate and create derivative works of this article (for both commercial and non-commercial purposes), subject to full attribution to the original publication and authors. The full terms of this license may be seen at: http://creativecommons.org/licences/by/4.0/legalcode

Vol. 11, No. 10, 2021, Pg. $1218-1226$

Full Terms \& Conditions of access and use can be found at http://hrmars.com/index.php/pages/detail/publication-ethics 


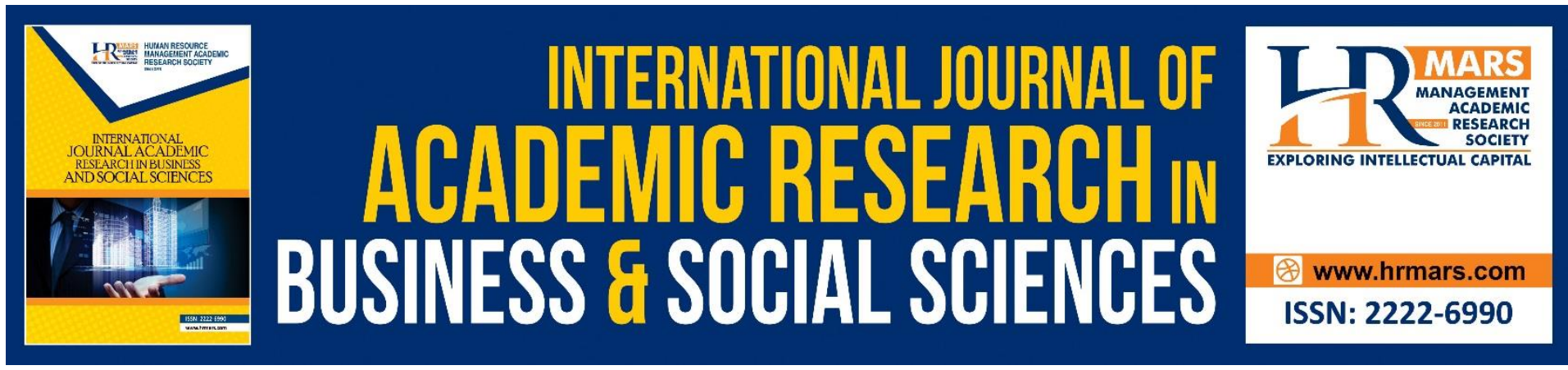

\title{
Contribution of Emotional Intelligence and Job Stress toward Job Satisfaction among Lecturers of Polytechnic
}

\author{
Nurfatin Diyana Hisya Muddin, Hazalizah Hamzah \\ Department of Psychology and Counseling, Faculty of Human Development, Universiti \\ Pendidikan Sultan Idris, 35900 Tanjong Malim, Perak Darul Ridzuan, Malaysia.
}

\begin{abstract}
The purpose of this research was to determine the contribution of emotional intelligence and job stress toward job satisfaction. Therefore, a paper-and-pencil survey method was employed in the research. Responses from 69 Polytechnic lecturers were gathered with 47 of them were females. The survey was conducted by using a standardized set of questionnaires for each of the variable used which were USM Emotional Quotient inventory (USMEQ-i), Effort and Reward Imbalance scale (ERI) and Job Satisfaction Survey (JSS) in the study. Descriptive analysis was used, and Multiple Regression was also employed to test the hypotheses. The result indicated that there was only job stress showed negatively significant contributed the job satisfaction. Thus, all the dimensions of emotional intelligence show no contribution to job satisfaction.
\end{abstract}

Keywords: Emotional Intelligence, Job Stress, Job Satisfaction, Lecturers, Polytechnic

\section{Introduction}

Job satisfaction is one of the main variables in ensuring the effectiveness of an organization. For the lecturer, job satisfaction is critical since it can help them become better and more productive in their profession (Ahmad \& Abdurahman, 2015). However, there was a negative relationship between job satisfaction and job stress (Khan, Aqeel \& Riaz, 2014). Hence, this shows that lecturers that experienced job stress might affect their satisfaction in their job. Meanwhile, the employee that has high emotional intelligence can manage their stressful situation effectively (Mohamed \& Nagy, 2017). Besides that, the employee with emotional intelligence play's role in achieving the satisfaction and success in the workplace (Akomolafe \& Ogunmakin, 2014). This shows that emotional intelligence is an important aspect of a lecturer to be satisfied with their job.

However, there were some gaps to exist regarding the relationship between emotional intelligence and job satisfaction as there was only a few researches conducted toward lecturers (Kassim, Bambale \& Jakada, 2016). Tharek (2011) stated that job stress among lecturers in higher institution of Malaysia are less likely to be documented as might be because of lack report received. Thus, the present research was aiming to identify the level of job stress that link to job satisfaction, as Khan et al (2014) discovered that job stress was 
significantly associated with job satisfaction. Hence, present research aims to measure the contribution of emotional intelligence and job stress toward job satisfaction.

Each of the variable was measured by using a standardized questionnaire. This is explained further in the study, research method section. The present research expected to make awareness of the lecturer regarding level of stress experienced by them in the workplace. Finally, the research expected to contribute some related research and analysed data to other research for future study ahead.

\section{Literature Review}

Employees that were able to achieve the job satisfaction parameters indicated that they were happy with their job (Sumedho, 2015). With that in mind, job satisfaction is an important aspect that has been used with different findings (Kassim et al., 2016). In any organization, job satisfaction plays a vital role. However, Ahmad and Abdurahman (2015) found that there was still least number of lecturers have experienced a high level of job satisfaction.

Emotional intelligence could be defined as the ability to perceive, express, understand, motivate, control and regulate emotion (Yusoff, Rahim \& Esa, 2010). According to Hassan, Jani, Som, Hamid and Azizam (2015), lecturers should be well-versed in a useful aspect of teaching that is emotional intelligence. This is because, emotional intelligence is an individual factor that has a close relationship with job satisfaction (Ouyang et al., 2015). On the other hand, emotional intelligence does have help in managing and reducing the job stress experienced. According to Mohamed and Nagy (2017), the employee that has high emotional intelligence can manage their stress effectively.

Employees that experienced effort-reward imbalance at work are certainly distressing as it may contradict with the basic expectations of equivalence of return in costly transactions in the workplace based on Siegrist (2016). According to Pan et al (2015), factors connected with job satisfaction are clarified. It was found that the university teachers were experienced occupational stress due to immense workload. The researcher stated that occupational stress had a negative impact on job satisfaction. There was also suggested that effective measures be taken to promote job satisfaction by reducing occupational stress. The stress of work plays a role to predict the job satisfaction.

Overall, there were nine hypotheses that were built and tested in the present research. The hypotheses were as follows:

$\mathrm{H}_{1} 1$ : Emotional intelligence and job stress will significantly contribute to job satisfaction.

$\mathrm{H}_{1} 1 \mathrm{a}$ : Emotional control of emotional intelligence will significantly contribute to job satisfaction.

$\mathrm{H}_{1} \mathrm{lb}$ : Emotional maturity of emotional intelligence will significantly contribute to job satisfaction.

$\mathrm{H}_{1} 1 \mathrm{c}$ : Emotional conscientiousness of emotional intelligence will significantly contribute to job satisfaction. 
$\mathrm{H}_{1} 1 \mathrm{~d}$ : Emotional awareness of emotional intelligence will significantly contribute to job satisfaction.

$\mathrm{H}_{1} 1 \mathrm{e}$ : Emotional commitment of emotional intelligence will significantly contribute to job satisfaction.

$\mathrm{H}_{1} 1 \mathrm{f}$ : Emotional fortitude of emotional intelligence will significantly contribute to job satisfaction.

$\mathrm{H}_{1} 1 \mathrm{~g}$ : Emotional expression of emotional intelligence will significantly contribute to job satisfaction.

$\mathrm{H}_{1} 1 \mathrm{~h}$ : Job stress will significantly contribute to job satisfaction.

\section{Research Method}

Survey design was used to collect the respondent's answer regarding how the variables of emotional intelligence and job stress could contribute to the job satisfaction of a lecturer. Paper-and-pencil survey were given towards lecturers of polytechnic which consists of the standardized questionnaire for measuring the variables.

The research was conducted toward polytechnic lecturers, and according to Kementerian Pendidikan Malaysia website (information retrieved on $16^{\text {th }}$ Mei 2019), the population of the polytechnic lecturers were 241 numbers. Thus, the optimum sample size obtained was 148 participants that was determined through Krejcie and Morgan sample size formula (Mohd \& Diyana, 2012) for finite population by using the formula as follows.

$$
=\frac{X^{2} N P(1-P)}{d^{2}(N-1)+X^{2} P(1-P)}
$$

Random sampling method was used initially to select the sample due to this method allowed sample to get equal chances of being selected in the research by using table of random number (Shaughnessy et al., 2012). Initially, 150 surveys were distributed via random sampling, but this had to be changed to convenience sampling due to a shortage of participants and the lecturer's other obligations.

The population of polytechnic lecturers were from six faculties in the polytechnic. There were 73 responses obtained from participants. However, a total of 69 responses were being analysed by the researcher as the 4 of the responses were being deleted due to extreme responses. Distribution of participants by demographic information of the age stated based on mean for age was $M=40.13(S D=5.56)$ based on a total of 69 participants. Demographic information of the participants was shown in the TABLE 1.

The analysis of the data collected is used by the researcher were descriptive analysis and multiple regression. To explore if there was a link between emotional intelligence and job stress toward job satisfaction, a descriptive analysis was carried out. 
Table 1. Distribution by demographic information

\begin{tabular}{lll}
\hline Demographic information & Frequency $(f)$ & $\begin{array}{l}\text { Percentage } \\
(\%)\end{array}$ \\
\hline Gender & & 31.90 \\
$\quad$ Male & 22 & 68.10 \\
$\quad$ Female & 47 & \\
\hline Race & & 4.30 \\
$\quad$ Chinese & 3 & 1.40 \\
Indian & 1 & 94.20 \\
Malay & 65 & \\
\hline Departments & & 15.90 \\
$\quad$ Electrical engineering & 11 & 21.70 \\
Mechanical engineering & 15 & 5.80 \\
Mathematics, science and computer & 4 & 13.00 \\
$\quad$ General studies & 9 & 31.90 \\
$\quad$ Commerce & 22 & 11.60 \\
$\quad$ Information and communication technology & 8 & \\
\hline Grand total & 69 & \\
\hline
\end{tabular}

\section{Results}

All the scores for each item were being calculated to get total of emotional intelligence. The level of emotional intelligence dimensions also was presented to explain further about the dimensions. Based on TABLE 2, there showed a mean for total of emotional intelligence were $M=3.27(S D=0.42)$ that indicate a high level of emotional intelligence experienced by the lecturers. Further detailed, all the emotional intelligence dimensions showed high level of emotional intelligence dimension.

Table 2. Level of Emotional Intelligence and Its Dimensions

\begin{tabular}{lll}
\hline & Mean $(M)$ & Std. Deviation $(S D)$ \\
\hline Total emotional intelligence & 3.27 & 0.42 \\
Emotional control & 3.09 & 0.49 \\
Emotional maturity & 3.38 & 0.48 \\
Emotional conscientiousness & 3.52 & 0.45 \\
Emotional awareness & 3.24 & 0.50 \\
Emotional commitment & 3.19 & 0.61 \\
Emotional fortitude & 3.15 & 0.57 \\
Emotional expression & 3.51 & 0.39 \\
\hline
\end{tabular}

All the scores for each item were being calculated to get a total score of job stress. The level of stress was presented according to the range score of ERI scale scoring process to further explain the imbalance experienced by the lecturers in favour of effort or reward. Based on TABLE 3, showed all of the lecturers experienced imbalance between effort and reward with imbalance in favour of reward. The mean for the total score of job stress were $M=0.95(S D=0.29)$ that indicate there were an imbalance in favour of reward among 69 lecturers of polytechnic from six departments. 
Table 3. Level of job stress

\begin{tabular}{lll}
\hline & Frequency $(f)$ & Percentage (\%) \\
\hline$E R<1$ & 40 & 57.97 \\
$E R>1$ & 26 & 37.68 \\
$E R=1$ & 3 & 4.35 \\
\hline Total & 69 & 100.00
\end{tabular}

Total scores for each item were being summed up to get a total score of job satisfaction. The level of job satisfaction was presented according to the range score. Based on TABLE 4, showed most of the lecturers satisfied with their job meanwhile only a few numbers of lecturers dissatisfied with their job and some of them were ambivalent toward the job. The mean for the total score of job satisfaction were $M=163.43(S D=23.47)$ that indicate a high level of job satisfaction experienced.

Based on TABLE 5, showed that $F(8,60)=7.92, p=0.00, R^{2}=0.51$. Based on adjusted $R^{2}, 45 \%$ variance of dependent variable were contributed by predictors based on the adjusted $R^{2}$. The coefficient for contribution of emotional intelligence and job stress toward job satisfaction shown in TABLE 6, showed that the job stress was the only predictor for job satisfaction with $(b=-0.64, p=0.00)$. However, the remaining dimensions of emotional intelligence were not statistically significant impact on job satisfaction. Thus, only $\mathrm{H}_{1} \mathrm{lh}$ was accepted meanwhile remaining alternative hypotheses were rejected.

Table 4. Model of summary for contribution of emotional intelligence dimension and job stress toward job satisfaction

\begin{tabular}{llll}
\hline$R$ & R Square & Adjusted R Square & Std. Error of the Estimate \\
\hline 0.72 & 0.51 & 0.45 & 17.43 \\
\hline
\end{tabular}

a. Predictors: (Constant), Job stress, Emotional conscientiousness, Emotional commitment, Emotional awareness, Emotional expression, Emotional fortitude, Emotional maturity, Emotional control

b. Dependent variable: Job satisfaction 
Table 5. Coefficient for contribution of emotional intelligence dimensions and job stress toward job satisfaction

\begin{tabular}{|c|c|c|c|c|c|}
\hline \multirow[b]{2}{*}{ Model } & \multicolumn{2}{|c|}{$\begin{array}{l}\text { Unstandardized } \\
\text { Coefficients }\end{array}$} & \multicolumn{2}{|l|}{$\begin{array}{l}\text { Standardized } \\
\text { Coefficients }\end{array}$} & \multirow[b]{2}{*}{ Sig. } \\
\hline & B & Std. Error & Beta & $t$ & \\
\hline (Constant) & 187.16 & 23.41 & & 7.99 & 0.00 \\
\hline Emotional control & -16.59 & 8.85 & -0.35 & -1.88 & 0.06 \\
\hline Emotional maturity & -2.92 & 8.34 & -0.06 & -0.35 & 0.73 \\
\hline $\begin{array}{l}\text { Emotional } \\
\text { conscientiousness }\end{array}$ & 6.63 & 8.86 & 0.13 & 0.75 & 0.46 \\
\hline Emotional awareness & 7.35 & 6.74 & 0.16 & 1.09 & 0.28 \\
\hline $\begin{array}{l}\text { Emotional } \\
\text { commitment }\end{array}$ & 10.14 & 6.02 & 0.27 & 1.69 & 0.10 \\
\hline Emotional fortitude & 3.38 & 6.33 & 0.08 & 0.53 & 0.60 \\
\hline Emotional expression & -0.74 & 8.97 & -0.01 & -0.08 & 0.93 \\
\hline Job stress & -52.42 & 7.67 & -0.64 & -6.83 & 0.00 \\
\hline
\end{tabular}

a. Dependent Variable: Job satisfaction

\section{Discussion and Conclusions}

The result obtained showed that only job stress showed negatively significant predictor toward job satisfaction. Lecturers of polytechnic also showed a high level of job satisfaction toward their work based on the score obtained. Meanwhile, the lecturers also experienced job stress and have a high level of emotional intelligence based on the score obtained.

Overall, lecturers showed high level of emotional intelligence as may be due to high emotional demand in the teaching process (Hassan et al., 2015). Lecturers who were discovered to experience job stress as there was the existence of imbalance between effort and reward. According to Mohamed and Nagy (2017), their research showed that there were majority of academic members had job stress might be due to most of the lecturers in the research were stressed and others were exhausted (Masuku \& Muchemwa, 2015). Results were also indicated that the lecturers experienced a high level of job satisfaction as might be due to the work environment (Ahmad \& Abdurahman, 2015).

According to Khan et al (2014) job stress has a significant negative relationship with job satisfaction that align with current studies. Based on Pan et al (2015), also stated that occupational or job stress also had negative impact on job satisfaction. Essiam, Mensah, Kudu and Gyamfi (2015) also conducted a study that found job satisfaction was explained by job stress although the overall effect size was practically small. Hence, according to past studies, job stress does have a role in job satisfaction.

However, the current study contradicts a prior study that found by Ismail, Yao, Yeo, Lai-Kuan and Soon (2010) who discovered that emotional intelligence is a partial moderator among academic employees. Akomolafe and Ogunmakin (2014) also found that emotional 
intelligence important in predicting job satisfaction. As a result, the current study appears to be contradicted with past findings.

This study has several limitations. First, the research conducted was non-probability sampling, which was convenience sampling adopted, although initially the research planned to use random sampling. Second, the research was conducted during examination of the students and there were some lecturers that went course during the period, resulting in the absence of a large number of lecturers.

Thus, the research should be conducted during lecture and classes week rather than examination week. Furthermore, there was also need to expand the duration to conduct the research to increase the number of sample size. Besides that, the research need to be conducted on diverse sampling that include other institution rather than same institution only.

In conclusion, the lecturers experienced a high level of job satisfaction despite them experiencing job stress. The lecturers also obtained a high level of emotional intelligence. However, only job stress showed negatively significant as a predictor toward job satisfaction.

\section{Acknowledgement}

The author would like to thanks Universiti Pendidikan Sultan Idris and polytechnic for helping in research conducted.

\section{Corresponding Author}

The author would like to express deepest appreciation to the respectful supervisor, Assoc. Prof. Dr. Hazalizah Binti Hamzah from Universiti Pendidikan Sultan Idris, for guiding, teaching, and spending time and effort while giving an inspiration that will be forever cherish. The author also would like to thanks to polytechnic lecturers who have allowed and participated in this study.

\section{References}

Ahmad, W. I. W., \& Abdurahman, S. M. (2015). Job satisfaction among academic staff of Universiti Utara Malaysia: A work environment perspective. Mediterranean Journal of Social Sciences, 6(3), 251-256. Retrieved from http://www.mcser.org/journal/index.php/mjss/article/view/6492

Akomolafe, M. J., \& Ogunmakin, A. O. (2014). Job satisfaction among secondary school teachers: Emotional intelligence, occupational stress and self-efficacy as predictors. Journal of Educational and Social Research, 4(3), 487-498. Retrieved from https://www.mcser.org/journal/index.php/jesr/article/viewFile/2752/2717

Essiam, J. O., Mensah, M. E., Kudu, L. K., \& Gyamfi, G. D. (2015). Influence of job stress on job satisfaction among university staff: analytical evidence from a public university in Ghana. International Journal of Economics, Commerce and Management, 3(2), 1-15. Retrieved from http://citeseerx.ist.psu.edu/viewdoc/download?doi=10.1.1.677.3237\&rep=rep1\&type $=$ pdf

Hassan, N., Jani, M. S., Som, R., Hamid, N. Z. A., \& Azizam, N. (2015). The relationship between emotional intelligence and teaching effectiveness among lecturers at Universiti 
Teknologi MARA, Puncak Alam, Malaysia. International Journal of Social Science and Humanity, 5(1), 1-5. Retrieved from http://www.ijssh.org/papers/411-H00001.pdf

Ismail, A., Yao, A., Yeo, E., Lai-Kuan, K., \& Soon. (2010). Occupational stress features, emotional intelligence and job satisfaction: An empirical study in private institutions of higher learning. Negotium, 6(16), 5-33. Retrieved from

https://www.redalyc.org/pdf/782/78216323002.pdf

Kassim, S. I., Bambale, A. J., \& Jakada, B. A. (2016). Emotional Intelligence and Job Satisfaction among Lecturers of Universities in Kano State: Empirical Evidence. Journal of Education and Practice, 7(10), 53-59. Retrieved from

https://files.eric.ed.gov/fulltext/EJ1099468.pdf

Kementerian Pendidikan Malaysia. (n.d.). Retrieved May 16, 2019, from Politeknik Malaysia Seberang Perai:

http://www.psp.edu.my/pspweb/index.php?option=com_content\&view=article\&id=1 58\&ltemid=278\&lang $=m s-m y$

Khan, E. A., Aqeel, M., \& Riaz, M. A. (2014). Impact of job stress on job attitudes and life satisfaction in college lecturers. International journal of information and education Technology, 4(3), 270-273. Retrieved from http://www.ijiet.org/papers/411N00020.pdf

Masuku, S., \& Muchemwa, S. (2015). Occupational stress among university lecturers: A case of Zimbabwe. US-China Education Review, 5(4), 258-266. Retrieved from http://www.davidpublisher.com/Public/uploads/Contribute/55470a9924e1e.pdf

Mohamed, S. M., \& Nagy, F. (2017). Emotional intelligence and job stress among academic members at faculty of nursing - Cairo University. Journal of Nursing and Health Science, 6(1), 10-19. Retrieved from https://pdfs.semanticscholar.org/1de4/3dfa0b5181e9

Mohd, G. A., \& Diyana K. (2017). Survey Research in Social Science with Complete Sample. Pahang: Universiti Malaysia Pahang.

Ouyang, Z., Sang, J., Li, P., \& Peng, J. (2015). Organizational justice and job insecurity as mediators of the effect of emotional intelligence on job satisfaction: A study from China. Personality and Individual Differences, 76, 147-152. Retrieved from https://www.sciencedirect.com/science/article/pii/S0191886914007120

Pan, B., Shen, X., Liu, L., Yang, Y., \& Wang, L. (2015). Factors associated with job satisfaction among university teachers in northeastern region of China: A cross-sectional study. International Journal of Environmental Research and Public Health, 12(10), 1276112775. Retrieved from https://www.mdpi.com/1660-4601/12/10/12761

Shaughnessy, J., Zechmeister, E. B., \& Zechmeister, J. S. (2012). Research Methods (Psychology, Ninth Edition ed.). New York: McGraw-Hill.

Siegrist, J. (2016). Effort-Reward Imbalance Model. In In Stress: Concepts, Cognition, Emotion, and Behavior (pp. 81-86). Duesseldorf, Germany: Academic Press.

Sumedho, S. (2015). The Effect of Nine Facets of Job Satisfaction for Creative Employees in Creative Agency. iBuss Management, 3(1), 21-27. Retrieved from http://publication.petra.ac.id/index.php/ibm/article/download/2940/2644

Tharek, M. (2011). Tekanan Kerja Dan Kepuasan Kerja Pensyarah Universiti Teknologi Malaysia. 1-45. Retrieved from http://eprints.utm.my/id/eprint/39756/5/MushirahTharekMFPPSM2011.pdf

Yusoff, M. S. B., Rahim, A. F. A., \& Esa, A. E. (2010). The USM emotional quotient inventory (USMEQ-i) manual. Universiti Sains Malaysia. 